\title{
PENGOLAHAN LIMBAH LABORATORIUM KIMIA DENGAN SISTEM PENYARINGAN SEDERHANA
}

\author{
Arinal Fajri' ${ }^{*}$, Dora Arista1, Maya Sari ${ }^{1}$ \\ ${ }^{1}$ Tadris Kimia, Fakultas Tarbiyah dan Ilmu Keguruan, Institut Agama Islam Negeri Batusangkar \\ Jalan Sudirman No. 137 Lima Kaum Batusangkar, Kab. Tanah Datar \\ *Email: arinalfajri08@gmail.com
}

\begin{abstract}
Increasing uses of chemicals in the laboratory result of waste substances increased. If those wastes are not carefully managed, various pollutions in the environment will occur. The research deals with the use of a simple filtering for laboratory type liquid waste before disposal. This study took the wastewater IAIN Batusangkar chemical laboratory as the object of research. The tools used to measure the concentration of waste are $\mathrm{pH}$ meters and TDS meters, with waste analysis before filtering are color: orange, temperature: $25.5^{\circ} \mathrm{C}, \mathrm{pH}$ : 3.1 , TDS (dissolved solids): 11.16 , Salt (salinity level ): 8.38 , COND: $16.78 \mathrm{mS}$ and a waste volume of $300 \mathrm{ml}$ filtered using simple tools and materials, tools with a height of $23 \mathrm{~cm}$ and supported with such materials as sponges, wood charcoal, sand, gravel, coconut fiber, cotton, small stone, with a height of each material in the tool that is $3.5 \mathrm{~cm}$. The results shows that the simple filtering instrument for laboratory waste worked quite well, with a one-time analysis of waste where the results are as follow color: clear, temperature: $25.3^{\circ} \mathrm{C}, \mathrm{pH}$ : 6.2 , TDS: 13.23 , SALD: 9.93 , COND: $19.88 \mathrm{mS}$, volume of waste: 150 $\mathrm{ml}$. It can be concluded that filtering is successfully filtered waste is approaching the normal $\mathrm{pH}$ of pure water that is 7 .
\end{abstract}

Keywords: chemical laboratory waste, $\mathrm{pH}$, TDS.

\section{PENDAHULUAN}

Limbah laboratorium Tadris Kimia Institut Agama Islam Negeri Batusangkar merupakan limbah yang mengandung bahan kimia bersifat asam dan basa. Limbah tersebut merupakan sisa bahan kimia yang digunakan dalam praktikum. Limbah cair Laboratorium Tadris Kimia Fakultas Tarbiyah dan Ilmu Keguruan, yang dihasilkan dari kegiatan praktikum dikumpulkan dalam suatu wadah dan belum dilakukan pengolahan, sehingga terjadi penumpukkan. Berdasarkan zat yang terkandung di dalam limbah cair laboratorium secara kolektif dan dalam kurun waktu yang lama apabila dibuang langsung ke lingkungan akan mencemari lingkungan, seperti merusak struktur tanah, mengancam kelangsungan hidup ekosistem air maupun darat, serta berdampak bagi kesehatan manusia.
Berdasarkan peraturan Pemerintah Republik Indonesia Nomor: 18 Tahun 1999, bahwa unsur yang terkandung dalam air limbah laboratorium termasuk senyawa bahan berbahaya dan beracun (B3). Penanganan dan pengelolaan limbah bahan berbahaya dan beracun sangat perlu diperhatikan, mengingat bahaya yang akan ditimbulkan. Oleh karena itu pada penelitian ini akan dibuat pengolahan limbah cair Laboratorium Tadris Kimia IAIN Batusangkar. Banyak teknologi yang dapat diterapkan untuk melakukan pengolahan limbah antara lain: proses koagulasi-flokulasi, filtrasi, adsorpsi dan pertukaran ion dan membran sel (Crittenden, Trussell et al. 2012)

Pada penelitian ini menitikberatkan pada proses filtrasi dengan menggunakan bahan sederhana, Filtrasi merupakan proses pemisahan padatan-cairan dimana cairan akan 
Fajri, A., Arista, D., Sari, M. 2018. Pengolahan Limbah Laboratorium Kimia dengan Sistem Penyaringan Sederhana. Sainstek : Jurnal Sains dan Teknologi. 10 (1) : 20-23

melewati media berpori, sedangkan padatan akan tertahan. Filtrasi dalam pengolahan air limbah (wastewater treatment) digunakan untuk menyaring bahan-bahan kimia pengotor yang berukuran lebih besar.

Oleh karena itu pada penelitian ini akan dilakukan pengolahan limbah Laboratorium Tadris Kimia IAIN Batusangkar dengan sistem penyaringan sederhana atau filtrasi dengan menggunakan bahan-bahan sederhana yang mudah didapatkan seperti arang, pasir, kerikil, sabut kelapa dan spon. Tujuan penelitian adalah untuk mengetahui $\mathrm{pH}$, TDS, aroma, warna, volume dan suhu pada limbah Laboratorium Tadris Kimia IAIN Batusangkar serta mengetahui efektivitas perubahan dari $\mathrm{pH}$, TDS, warna, suhu, volume dan aroma limbah dengan sistem penyaringan sederhana.

\section{METODE PENELITIAN}

Penelitian dilakukan di laboratorium Tadris Kimia Fakultas Tarbiyah dan Ilmu Keguruan Institut Agama Islam Negeri Batusangkar. Alat yang digunakan dalam penelitian ini adalah tiga buah gelas kimia ukuran $500 \mathrm{ml}$, statif dan kleb, ph meter, TDS meter, botol bekas. sedangkan bahan yang digunakan adalah limbah Laboratorium Tadris Kimia IAIN batusangkar, spon dengan ketebalan $5 \mathrm{~cm}$, batu kerikil 40 gram, arang 30 gram, pasir halus 40 gram, sabut kelapa 30 gram, dan kapas 10 gram, Yang dilakukan dalam penelitian ini adalah

\section{Mengukur konsentrasi limbah}

Limbah yang digunakan adalah limbah Laboratorium Kimia IAIN Batusangkar sebanyak $300 \mathrm{ml}$ diukur menggunakan gelas kimia dan limbah tersebut diukur ph, TDS, suhu dengan menggunakan ph meter dan TDS meter.

\section{Menyusun bahan dalam alat}

Alat yang digunakan adalah botol dengan tinggi $23 \mathrm{~cm}$ dan diameter $7 \mathrm{~cm}$. Di dalam botol disusun bahan yaitu lapisan paling atas batu kecil, sabut kelapa, kapas, pasir halus, kapas, kerikil, kapas, arang, kapas dan spons dengan tinggi masing masing bahan dalam alat adalah 3,5 cm kecuali kapas, kapas hanya pemisah antara satu bahan dengan yang lain. Seperti pada Gambar 1.

\section{Penyaringan limbah dengan bahan sederhana}

Setelah bahan disusun maka mulai menyaring limbah. Limbah dengan volume 300 $\mathrm{ml}$ tersebut dimasukkan ke dalam alat saring secara perlahan. Penyaringan dilakukan $1 \mathrm{x}$ penyaringan. Setelah limbah disaring limbah tersebut diukur kembali dengn menggunakan $\mathrm{pH}$ meter dan TDS meter untuk membandingkan data sebelum dan sesudah limbah disaring.

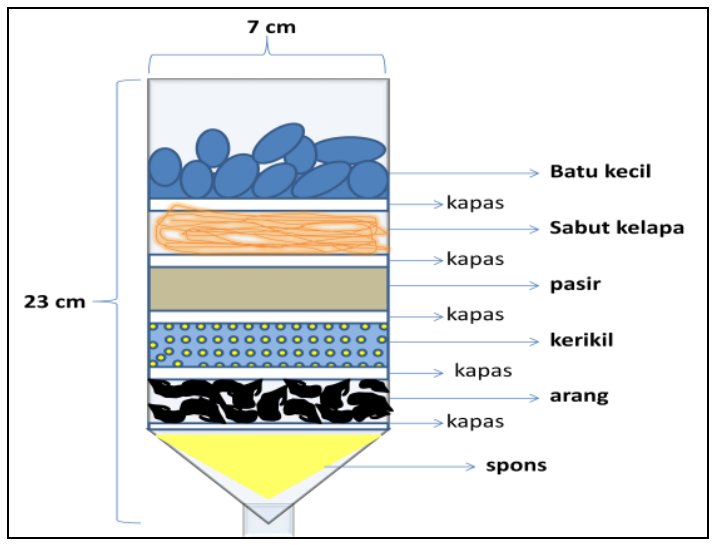

Gambar 1. Struktur Bahan dalam Alat 
Fajri, A., Arista, D., Sari, M. 2018. Pengolahan Limbah Laboratorium Kimia dengan Sistem Penyaringan Sederhana. Sainstek : Jurnal Sains dan Teknologi. 10 (1) : 20-23

\section{Teknik Analisa Data}

Analisis data dilakukan dengan metode deskriftif komperatif, dimana air limbah laboratorium yang telah dilakukan penyaringan dibandingkan dengan air limbah laboratorium sebelum dilakukan penyaringan untuk mendapatkan perbedaan, yang disajikan dalam bentuk tabel.

\section{HASIL DAN PEMBAHASAN}

Dari penelitian yang dilakukan di Laboratorium Tadris Kimia Fakultas Tarbiyah dan Ilmu Keguruan Institut Agama Islam Negeri (IAIN) Batusangkar tentang pengolahan limbah laboratorium kimia dengan sistem penyaringan sederhana, mendapatkan hasil bahwa terjadi perubahan kualitas limbah setelah dilakukan penyaringan dengan menggunakan bahan sederhana, dari hasil pengujian didapatkan analisis data sebagai berikut:

1. Data kualitatif

Tabel 1 Perbandingan Warna dan Bau Limbah

\begin{tabular}{llll}
\hline \multicolumn{1}{c}{ Pengamatan limbah } & \multicolumn{1}{c}{ Sebelum } & \multicolumn{1}{c}{ Sesudah } \\
\hline Warna & Orange & & Bening keruh \\
Bau & Berbau & & Bau berkurang \\
\hline
\end{tabular}

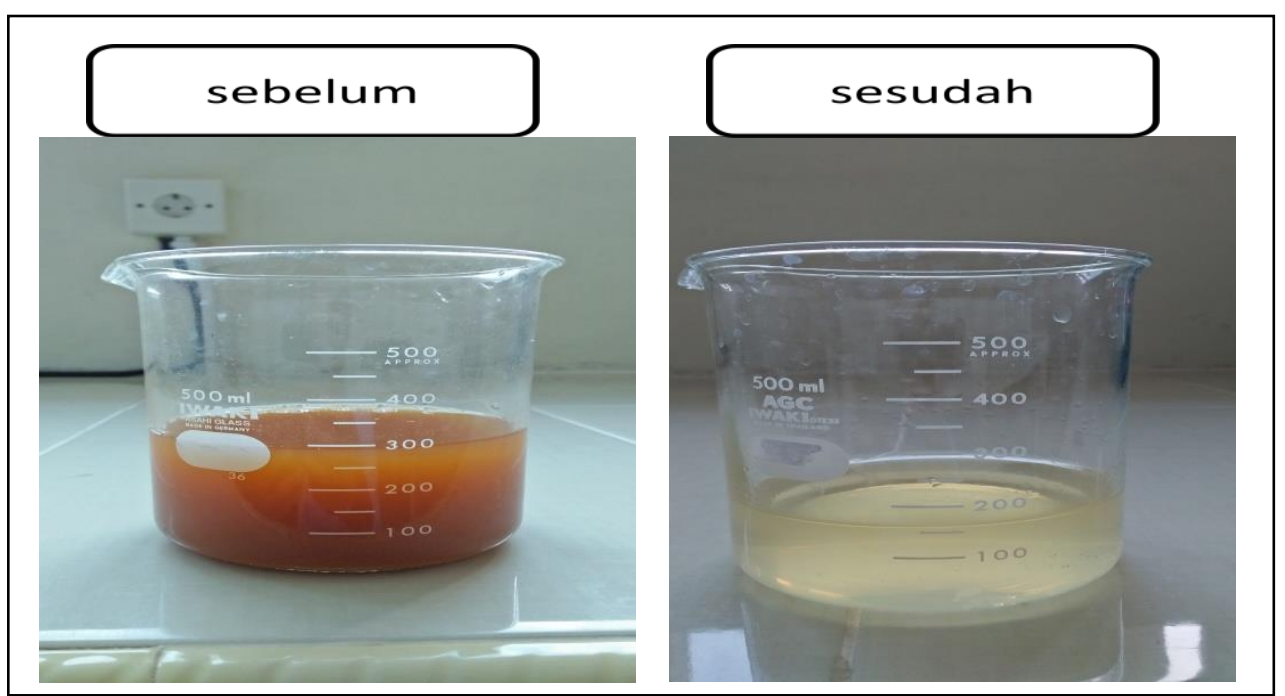

Gambar 2. warna limbah sebelum dan sesudah

2. Data kuantitatif

Tabel 2 Perbandingan ph, Suhu, Volume dan TDS Limbah

\begin{tabular}{lcc}
\hline \multicolumn{1}{c}{ Pengamatan Limbah } & Sebelum & Sesudah \\
\hline pH limbah & 3,1 & 6,2 \\
Suhu limbah & $25,5^{\circ} \mathrm{c}$ & $25,3^{\circ} \mathrm{c}$ \\
TDS & 11,16 & 13,23 \\
Volume limbah & $300 \mathrm{ml}$ & $150 \mathrm{ml}$ \\
\hline
\end{tabular}


Dari penelitian yang dilakukan bahwa yang mempengaruhi perubahan warna limbah adalah tingkat penyaringan limbah, semakin tebal dan banyak bahan-bahan yang digunakan dalam penyaringan limbah maka limbah yang dihasilkan semakin jernih.

Bahan yang berperan penting dari pembersihan warna limbah adalah sabut kelapa, pasir dan kerikil dikarenakan pori-pori bahan tersebut berukuran kecil hal itu membuat banyak pertikel limbah yang tersangkut pada bahan tersebut sedangkan arang berperan sebagai penghilang bau dari limbah dan juga sebagai pengubah warna limbah. Sebagaimana diterangkan Siti, 2014 adapun perubahan yang terjadi pada warna jernih setelah pemberian karbon yang berasal pada arang, dan dapat disebabkan terserapnya kandungan zat organik, zat besi atau logam dalam air oleh pori-pori karbon pada arang sehingga menjadikan air jernih.

Penyaringan dengan sistem sederhana dapat disebut pengolahan secara fisika karena dilakukan terhadap air buangan agar bahan tersuspensi yang berukuran besar mudah mengendap atau bahan yang terapung disisihkan dengan cara penyaringan (Al Madury, Fakhrunnisa et al: 2014). Dari penyaringan yang dilakukan menggunakan bahan sederhana, bahan-bahan tersebut menyaring limbah laboratorium kimia IAIN Batusangkar dengan perbedan ukuran partikel yang mana partikel besar akan tertahan pada bahan yang disusun pada alat. Hal itu membuat volume limbah setelah penyaringan lebih sedikit dibanding yang dimasukkan karena partikel-partikel besar pada limbah tertinggal pada alat, dan yang mempengaruhi lainnya adalah daya serap tiap bahan penyaringan.

\section{KESIMPULAN}

Berdasarkan penelitian yang dilakukan dapat disimpulkan bahwa penggunaan bahanbahan sederhana dalam menyaring limbah laboratorium kimia IAIN Batusangkar bekerja cukup efektif, di tandai dengan perubahan $\mathrm{pH}$ limbah dari 3,1 menjadi 6,2 mendekati $\mathrm{pH}$ normal (lihat Tabel 2) dan warna limbah yang semulanya berwarna orange keruh berubah menjadi bening keruh (lihat Tabel 1 dan Gambar 1). Bahan yang di susun dalam alat penyaringan, menyaring limbah dengan proses pemisahan padatan-cairan dimana cairan akan melewati media berpori dan padatan akan tertahan.

\section{DAFTAR KEPUSTAKAAN}

Al Madury, S., F. Fakhrunnisa, R. Panjaitan, S. Ni'mah and T. P. Chandra (2014). "Prohilila (Produksi Hidrogen Dari Limbah Laboratorium) Sebagai Mediator Energi Pembangkit Listrik Dengan Metode Fuel Cell." Khazanah: Jurnal Mahasiswa 6(2): 55-66.

Crittenden, J. C., R. R. Trussell, D. W. Hand, K. J. Howe and G. Tchobanoglous (2012). MWH's water treatment: principles and design, John Wiley \& Sons. Raimon. Pengolahan Air Limbah Laboratorium Terpadu Dengan Sistem Kontinyu. Jurnal Dinamika Penelitian Industri Vol. 22 No. 2 Tahun 2011

Anonim. (1999). Peraturan Pemerintah Republik Indonesia Nomor: 18 Tahun 1999 tentang Pengelolaan Limbah Bahan Berbahaya dan Beracun. Jakarta.

Riyal gusdi,dkk. Pembuatan Alat Penyaringan Air Sederhana Dengan Metode Fisika. Jurnal Nasional Ecopedon JNEP Vol. 4 No.1.2017

Siti Jamilatun. Pembuatan Arang Aktif dari Tempurung Kelapa dan Aplikasinya untuk Penjernihan Asap Cair. Jurnal Spektrum Industri, 2014, Vol. 12, No. 1 